\title{
Advances in mesenchymal stem cell-mediated gene therapy for cancer
}

\author{
Roisin M Dwyer ${ }^{1,2 *}$, Sonja Khan', Frank P Barry², Timothy O'Brien ${ }^{1,2}$ and Michael J Kerin¹
}

\begin{abstract}
Mesenchymal stem cells have a natural tropism for tumours and their metastases, and are also considered immunoprivileged. This remarkable combination of properties has formed the basis for many studies investigating their potential as tumour-specific delivery vehicles for suicide genes, oncolytic viruses and secreted therapeutic proteins. The aim of the present review is to discuss the range of approaches that have been used to exploit the tumour-homing capacity of mesenchymal stem cells for gene delivery, and to highlight advances required to realize the full potential of this promising approach.
\end{abstract}

\section{Introduction}

Despite significant advances in the field of gene therapy for cancer, two major obstacles remain that continue to limit the clinical potential of this approach: lack of tumour tropism of vectors, and stimulation of an immune response. These barriers preclude systemic administration of current vectors to efficiently target metastatic disease. The combination of cellular therapy and gene delivery is an attractive option as it will potentially protect the vector from immune surveillance, and will support targeted delivery of a gene or therapeutic protein to the tumour site.

\section{Mesenchymal stem cells}

Mesenchymal stem cells (MSCs) are nonhaematopoietic stem cells that have generated a significant amount of interest as a result of their apparent ability to home to the tumour site following systemic delivery. MSCs have an inherent ability both to self-renew and to differentiate into multiple lineages including osteoblasts, chondrocytes and

*Correspondence: roisin.dwyer@nuigalway.ie

'Division of Surgery, School of Medicine, Clinical Science Institute, National

University of Ireland Galway, Galway, Ireland

Full list of author information is available at the end of the article adipocytes [1]. The cells are readily isolated from the stromal compartment of bone marrow, along with a number of other sources including adipose tissue, trabecular bone and skeletal muscle [2]. Although a single marker for MSCs has not been isolated, a panel of specific antigens has been identified, including expression of CD105, CD73 and CD90 in $>95 \%$ of the culture, and an absence of CD14, CD34, CD19, HLA-DR and CD45 [3]. When introduced systemically to healthy animals, MSCs have been shown to home preferentially to the lung, liver and bone, and were found to a lesser extent in other tissues. Upon injury, however, the migratory pathway changes to preferentially target sites of injury [4].

Although MSCs have potential uses in regenerative medicine and a number of different disease models, the present review will specifically focus on their potential for targeted gene delivery in the context of cancer. This is an exciting area of research that has gained considerable momentum in recent years, with studies reporting engineered MSCs specifically targeting multiple tumour types followed by local secretion of therapeutic proteins (IFN $\beta$ [5-7], IL-2 [8,9], IL-12 [10-12], pigment epitheliumderived factor [13], NK4 [14], TNF-related apoptosis inducing ligand (TRAIL) [15-18]), expression of prodrug activating suicide genes (herpes simplex virus-thymidine kinase [19-21], cytosine deaminase [22]), and delivery of replicating oncolytic viruses [16,19,23-25]. A major advantage of MSCs in this setting is that they are considered immunoprivileged, possibly due to low expression of $\mathrm{Ag}(\mathrm{HLA}) \mathrm{MHC}$ class 1, and no expression of CD40, CD80 and CD86 [4]. The cells are also known to secrete prostaglandin, transforming growth factor beta and hepatocyte growth factor, which regulate the T-cell immune response, thereby decreasing the probability of a cytotoxic T-cell response to transduced cells [17].

Resident MSCs suppress both transient and continuous immune surveillance, which aims at facilitating the healing process [26]. This immune privilege in the context of cancer, however, has the potential to support tumour progression. Djouad and colleagues reported growth of B16 melanoma cells in allogenic animals only in the presence of MSCs, suggesting that protection from the host immune response supported tumour establishment 
[27]. Further studies by the same group revealed that MSCs administered in low numbers with Renca adenocarcinoma cells actually induced tumour rejection [28]. MSCs were also shown to inhibit outgrowth of colon carcinoma in rats, with complete inhibition seen when the number of MSCs were at least equal to the number of tumour cells. Tumour establishment using the mixed cell population was found to induce more infiltration of monocytes and granulocytes than the individual populations alone [29].

This observation may be explained by the fact that high numbers of MSCs have been shown to suppress alloreactive $\mathrm{T}$ cells, with very low numbers found to stimulate lymphocyte proliferation [30]. Indeed, additional evidence suggests that the context with which MSCs are introduced in vivo may influence their immune phenotype [26].

\section{Tumour tropism}

Tumour-specific migration of MSCs is not completely understood, but appears to be dependent upon the biological properties of the tumour microenvironment, as well as the native tropism of selected cells. Integration of MSCs into the tumour stroma is thought to be mediated by high local concentrations of inflammatory chemokines and growth factors. The tumour microenvironment is considered a site of chronic inflammation [31]. This environment may mediate MSC migration through secretion of soluble factors such as epidermal growth factor, vascular endothelial growth factor-A, fibroblast growth factor, platelet-derived growth factor, stromal-derived growth factor- $1 \alpha$ (SDF-1 $\alpha / C X C L 12)$, IL-8, IL-6, granulocyte-macrophage colony-stimulating factor, granulocyte colony-stimulating factor, Ang1, monocyte chemoattractant protein-1 (CCL2), haematopoietic growth factor, transforming growth factor beta-1 and urokinase-type plasminogen activator [32-37].

The process of MSC mobilization to the tumour is thought to be regulated similarly to leukocyte migration through integrins and adhesion molecules [38]. Molecules involved in leukocyte trafficking - such as tethering, rolling, adhesion and transmigration from the bloodstream to the tissue - are expressed on MSCs. These include integrins, selectins and chemokine receptors. Both P-selectin and vascular cell adhesion molecule-1 have been found to influence the adhesion of MSCs in endothelium [39].

MSCs express a wide range of molecules, including growth factors, chemokines, adhesion molecules and toll-like receptors, on their surface [38-44]. MSCs are known to functionally express chemokine receptors CCR1, CCR4, CCR7, CCR9, CCR10, CXCR4, CXCR5, CXCR6, CX3CR1 and c-met, which has been increasingly linked to tumour tropism [40-43]. The mechanism of MSC migration, however, is still not fully elucidated.
The most documented chemokine receptor implicated in targeted homing of MSCs is CXCR4, which has potential in cell mobilization and homing [45]. A study by Wynn and colleagues reported that CXCR4 is highly expressed on MSCs, but mainly intracellularly (83 to 98\%) rather than on the surface [46]. Another study reported no detectable CXCR4 expression on MSCs [42]. Variable expression of CXCR4 detected in different studies has been suggested to be related to sensitivity of the trypsin digestion procedure used [44], differences in culture conditions, and heterogeneity of MSC populations. In vitro three-dimensional culture of MSCs as spheroids was shown to increase SDF- $1 \alpha$ signalling, which restored functional expression of its receptor CXCR4 and homing potential that is crucial for therapeutic applications [47].

Although the tumour tropism of MSCs is generally accepted, it is certainly dependent on the tumour model. Variation in levels of MSC engraftment reported in different studies may be explained by differences in MSC isolation, culture conditions and experimental protocols used. Within individual studies, however, variable levels of MSC engraftment have been reported in different tumour types, most probably due to differences in the microenvironment created by the tumour in question [48]. The proportion of MSCs engrafted was not found to be related to tumour size [48].

A recent study further highlighted the role that the degree of inflammation in a tumour microenvironment plays in the level of MSC recruitment [7]. In a study of MSC-IFN $\beta$-mediated therapy of pancreatic cancer, treatment with an anti-inflammatory agent resulted in reduction of MSC engraftment in the tumour, and reversed the tumour inhibitory effects observed [7].

\section{Enhancing tumour tropism of mesenchymal stem cells} Modification of the tumour microenvironment

The apparent role of inflammation in MSC tumour tropism has also been harnessed to increase engraftment through tumour irradiation, which is associated with release of several cytokines from exposed tissue $[48,49]$. Klopp and colleagues found that low-dose irradiation of the tumour microenvironment enhanced MSC tropism and engraftment at the tumour site [49]. Irradiation resulted in apoptosis and increased release of inflammatory signals at the site of radiation, including TNF $\alpha$, platelet-derived growth factor, as well as chemokines CCL2 and CCR8 [49]. The effect of tumour radiotherapy on localization of lentivirus-transduced MSCs in a variety of tumour types has also been reported [48]. Irradiation increased MSC localization in LoVo, HT-29 (colon) and MDA-231 (breast), but not UMSCC1 (head and neck) xenografts. This study also reported a 
modest elevation in CCL2 expression in irradiated tumours, although it was not found to correlate with MSC infiltration [48]. Inflammation plays a critical role in tumour progression [50], and therefore stimulation to support MSC homing to tumours would not be a viable option. Radiotherapy is frequently a component of cancer therapy, however, and therefore could work in combination with MSC-based gene delivery to support improved targeting of MSCs to tumours.

\section{Modification of the mesenchymal stem cell surface}

While variations in MSC engraftment have been observed in different tumour models, attempts are being made to improve tumour tropism and infiltration through modification of the MSC surface. Cell rolling is a critical step of the adhesion cascade supporting rapid deceleration of cells from the bloodstream, and is mediated by selectins expressed on the endothelium of the target organ. Immobilized sialyl Lewis X on MSCs was shown to induce cell rolling on the P-selectin surface under dynamic shear flow conditions in vitro, and may have potential applications in improving MSC engraftment in vivo [51]. In one study where native MSC tropism for the tumour of interest was not detected, MSCs were engineered to overexpress the epidermal growth factor receptor - which binds transforming growth factor alpha and epidermal growth factor. Transduced MSCs had enhanced migratory properties towards GL261 gliomas or B16 melanoma in vivo [52]. Following establishment of improved engraftment, the cells were further engineered to secrete IFN $\gamma$, resulting in increased animal survival [52].

\section{Mesenchymal stem cell-mediated virus delivery}

A significant advantage of MSCs as cellular vehicles is their accessibility for genetic manipulation in vitro. Recent studies have incorporated the use of lentivirus-mediated transduction $[13,16,48,53]$, retrovirus-mediated transduction $[10,19,20,22]$ or plasmid-mediated transduction [21]; however, the majority remain adenovirus based [5-8,11,14,15,17,18,23-25,54,55]. MSCs have a low coxsackie and adenovirus receptor, high-integrin phenotype, which results in low transfection efficiency using wildtype adenoviruses. Modification of the adenovirus fibre or knob domain has been used to improve adenovirus-mediated transgene expression. Incorporation of an arginine-glysine-aspartate motif into the adenovirus fibre or the $5 / 3$ knob domain of human adenovirus serotype 3 supports coxsackie and adenovirus receptor-independent transfer and improves MSC transduction efficiency [14,23-25,55].

This approach has evolved to include the use of conditionally replicating adenoviruses, which support delivery of an increased viral load specifically to the tumour site [23-25]. Clearly the timing is important here to avoid toxicity to MSCs prior to engraftment at the target site. The cycle of MSC adenovirus replication has been reported to have relatively slow kinetics, which may allow time for MSCs to reach the target site before replication causes cell death [56]. The delivery of oncolytic viruses does not rely on long-term survival and proliferation of cellular vehicles, as they are destroyed by viral replication. Capsid-modified oncolytic adenoviruses have been coupled with the use of transcription-specific promoters to limit ectopic viral amplification in nontarget cells [55]. MSCs have also been engineered to express the herpes simplex virus-thymidine kinase followed by administration of the prodrug ganciclovir for targeted cancer suicide gene therapy [19-21]. Based on similar principles, retrovirus transduction of adiposederived MSCs to express cytosine deaminase, followed by systemic administration of the prodrug 5-fluorocysteine, mediated a strong anti-tumour effect in vivo [22].

\section{Localized delivery of therapeutic proteins}

Along with their tumour tropism, MSCs have been shown to integrate into and persist in the tumour stroma [5]. This integration has supported their use as delivery vehicles for various biological agents, whose systemic administration is precluded due to their short half-life and toxicity at the doses required for therapy. MSCs can efficiently produce biological products at tumour sites and so have the potential to improve pharmacokinetics of secreted agents [5].

In a number of tumour models, MSCs expressing IFN $\beta$ have been shown to result in decreased tumour burden and increased animal survival [5-7]. Increased systemic levels of IFN $\beta$ or secretion at sites distant from the tumour were not effective, indicating that regional secretion was required [5-7]. MSCs engineered to secrete IL-12 and embedded in a matrix adjacent to tumours were also reported to have a significant therapeutic effect [10]. Similar to findings in the case of IFN $\beta$, regional secretion was required, with no reduction in growth observed when the implant was placed in the opposite flank to the tumour [10].

MSCs expressing the hepatocyte growth factor antagonist NK4 in vivo were also found to prolong animal survival by inhibiting tumour-associated angiogenesis, lymphoangiogenesis and induction of cancer cell apoptosis [14]. Local secretion of pigment epithelium-derived factor in a model of hepatocellular carcinoma through lentivirus transduction of MSCs similarly resulted in lower tumour volume, reduced lung metastases and improved survival through inhibition of tumour angiogenesis [13].

Further, MSCs secreting IL-2 [8,9] or IL-12 [10,11] were shown to elicit an immunological reaction, and to 
stimulate inflammatory cell infiltration of the tumour tissue. The observed anticancer effect was shown to be immune mediated and absent in immunodeficient animals [10]. Delivery of MSC-IL-12 did not cause systemic toxicity, and resulted in increased serum and tumour levels of IL-12. In contrast, administration of Ad-IL-12 only increased serum IL-12 levels and induced systemic toxicity [11]. Therefore it appears that MSCmediated local delivery of a therapeutic agent may be better tolerated by the host without inducing an unacceptable immune response [11].

TRAIL induces caspase-mediated apoptosis in tumour cells that overexpress the receptor. Like most healthy tissues, MSCs are resistant to TRAIL-induced apoptosis due to their very low levels of active receptors [17]. As a result of this, MSCs secreting TRAIL have been used in models of lung cancer, breast cancer, cervical cancer and brain cancer in vivo, resulting in significant anti-tumour effects [15-18,53]. In one study using a lentiviral vector, TRAIL expression was placed under the control of a tet promoter, supporting conditional activation using doxycycline [16]. In an animal model of lung metastases of breast cancer, this controlled, local delivery of TRAIL completely cleared metastatic disease in a selection of animals [16]. Interestingly, when MSC-TRAIL cells were co-injected with tumour cells for subcutaneous tumour formation, only doxycycline-mediated activation on the day of tumour cell inoculation (day 0) caused a significant decrease in tumour weight. Activation following tumour establishment (day 25) did not result in a change in tumour burden [16].

\section{Potential role in tumourigenesis}

Although beyond the scope of the current review, the potential role of MSCs in tumour initiation or promotion is a significant concern that must be addressed fully to allow MSC-mediated therapy for cancer to realize its full potential. This role remains a topic of continued debate. Expansion of MSCs in vitro will be required for therapeutic application and so their stability in culture is paramount. Spontaneous transformation of human MSCs has been reported following long-term passage in vitro $[57,58]$, while Bernardo and colleagues found no evidence of human MSC transformation [59]. Indeed the majority of studies have shown that human MSCs are stable, while murine MSCs are more prone to genetic transformation during in vitro culture, and may be capable of forming sarcomas in vivo [59-63]. Although transformation of human MSCs appears unlikely, and very rare, these studies certainly emphasize the importance of stringent monitoring of MSCs, including karyotyping, before application in the clinical setting.

MSCs have also been implicated as tumour supportive when co-injected in the presence of a variety of tumour cell types, including breast [64-67], ovarian [68], melanoma [27], glioma $[69,70]$ and colon $[71,72]$ tumour cells. The majority of these studies, however, used an equal or even excess number of MSCs over tumour cells. The data generated provide important information on interactions between MSCs and tumour cells, although the models are unlikely to reflect the in vivo situation. MSCs were shown to integrate into the tumour stroma and were demonstrated to exert their effects at least partly through secretion of paracrine factors including CCL5, IL-6 and SDF-1 $\alpha[64,65,68]$. There is also evidence that MSCs may serve as precursors for carcinoma-associated fibroblasts and/or pericytes, playing a potentially important role in tumour angiogenesis through differentiation and the release of proangiogenic factors [67-69,71-76]. Additionally, as previously mentioned, the immunosuppressive qualities of MSCs may support tumour development and progression through protection of cancer cells from immune surveillance [27].

Conversely, co-injection of MSCs has also been shown to result in tumour suppression in a model of colon cancer [29], hepatoma [77] and melanoma [78].

In terms of MSC-mediated gene delivery, understanding the role of MSCs following engraftment at the site of a pre-established tumour is required. The majority of studies outlined here, using MSCs engineered to deliver therapeutic agents, have resulted in significant antitumour effects in vivo. Unmodified MSCs were also shown to result in tumour suppression in some cases $[7,8,79]$, with the majority showing no effect on tumour progression following engraftment at the site of an established tumour $[13,18,23,53,55,69,75]$. Repeat intravenous administration of MSCs over 3 weeks, however, was shown to stimulate increased tumour growth in a model of pancreatic cancer [21]. Similar to the level of MSC engraftment in tumours, it seems that the effect of MSCs following engraftment will be tumour specific probably dependent on a range of factors including the method of MSC isolation and culture, the experimental model, the number of cells engrafted in the tumour, and the milieu of growth factors and inflammatory cytokines present within the tumour microenvironment.

\section{Conclusion}

The studies outlined highlight very promising potential for MSC-mediated delivery of therapeutic agents directly to tumour tissue, with remarkable progress made in the past decade. Clearly MSCs have a number of advantages as cellular vehicles - they are relatively easy to isolate and expand, specifically target tumours and their metastases following systemic delivery, can be transduced efficiently with a range of vectors, have immunosuppressive properties, have the ability to express therapeutic proteins in secretory form and can support amplification 
of oncolytic viruses. The potential for MSC-mediated tumour promotion, however, must be addressed. Further understanding the biology of MSCs, and the specific combination of factors controlling their tumour-specific migration and persistence, will support translation to the clinical setting.

\section{Abbreviations}

Ad, adenovirus; IFN, interferon; IL, interleukin; MHC, major histocompatibility complex; MSC, mesenchymal stem cell; SDF-1a, stromal-derived growth factor-1 a (CXCL12); TNF, tumour necrosis factor; TRAIL, TNF-related apoptosis inducing ligand.

\section{Competing interests}

The authors declare that they have no competing interests.

\section{Acknowledgements}

Funding was received from the National Breast Cancer Research Institute, the Health Research Board of Ireland and Science Foundation Ireland.

\section{Author details}

'Division of Surgery, School of Medicine, Clinical Science Institute, National University of Ireland Galway, Galway, Ireland. ${ }^{2}$ Regenerative Medicine Institute, Orbsen building, National University of Ireland Galway (NUIG), Galway, Ireland.

Published: 9 August 2010

\section{References}

1. Pittenger MF, Mackay AM, Beck SC, Jaiswal RK, Douglas R, Mosca JD, Moorman MA, Simonetti DW, Craig S, Marshak DR: Multilineage potential of adult human mesenchymal stem cells. Science 1999, 284:143-147.

2. Barry FP, Murphy JM: Mesenchymal stem cells: clinical applications and biological characterization. Int J Biochem Cell Biol 2004, 36:568-584.

3. Dominici M, Le Blanc K, Mueller I, Slaper-Cortenbach I, Marini F, Krause D, Deans R, Keating A, Prockop D, Horwitz E: Minimal criteria for defining multipotent mesenchymal stromal cells. The International Society for Cellular Therapy position statement. Cytotherapy 2006, 8:315-317.

4. Kidd S, Spaeth E, Klopp A, Andreeff M, Hall B, Marini FC: The (in) auspicious role of mesenchymal stromal cells in cancer: be it friend or foe. Cytotherapy 2008, 10:657-667.

5. Studeny M, Marini FC, Champlin RE, Zompetta C, Fidler IJ, Andreeff M: Bone marrow-derived mesenchymal stem cells as vehicles for interferon-beta delivery into tumors. Cancer Res 2002, 62:3603-3608.

6. Nakamizo A, Marini F, Amano T, Khan A, Studeny M, Gumin J, Chen J, Hentschel S, Vecil G, Dembinski J, Andreeff M, Lang FF: Human bone marrow-derived mesenchymal stem cells in the treatment of gliomas. Cancer Res 2005, 65:3307-3318.

7. Kidd S, Caldwell L, Dietrich M, Samudio I, Spaeth EL, Watson K, Shi Y, Abbruzzese J, Konopleva M, Andreeff M, Marini FC: Mesenchymal stromal cells alone or expressing interferon-beta suppress pancreatic tumors in vivo, an effect countered by anti-inflammatory treatment. Cytotherapy 2010. [Epub ahead of print]

8. Nakamura K, Ito Y, Kawano Y, Kurozumi K, Kobune M, Tsuda H, Bizen A, Honmou O, Niitsu Y, Hamada H: Antitumor effect of genetically engineered mesenchymal stem cells in a rat glioma model. Gene Therapy 2004 , 11:1155-1164.

9. Stagg J, Lejeune L, Paquin A, Galipeau J: Marrow stromal cells for interleukin-2 delivery in cancer immunotherapy. Hum Gene Ther 2004 15:597-608

10. Eliopoulos N, Francois M, Boivin MN, Martineau D, Galipeau J: Neo-organoid of marrow mesenchymal stromal cells secreting interleukin- 12 for breast cancer therapy. Cancer Res 2008, 68:4810-4818.

11. Chen X, Lin X, Zhao J, Shi W, Zhang H, Wang Y, Kan B, Du L, Wang B, Wei Y, Liu $Y$, Zhao X: A tumor-selective biotherapy with prolonged impact on established metastases based on cytokine gene-engineered MSCs. Mol Ther 2008, 16:749-756.

12. Duan X, Guan H, Cao Y, Kleinerman ES: Murine bone marrow-derived mesenchymal stem cells as vehicles for interleukin-12 gene delivery into Ewing sarcoma tumors. Cancer 2009, 115:13-22.
13. Gao Y, Yao A, Zhang W, Lu S, Yu Y, Deng L, Yin A, Xia Y, Sun B, Wang X: Human mesenchymal stem cells overexpressing pigment epithelium-derived factor inhibit hepatocellular carcinoma in nude mice. Oncogene 2010, 29:2784-2794

14. Kanehira M, Xin H, Hoshino K, Maemondo M, Mizuguchi H, Hayakawa T, Matsumoto K, Nakamura T, Nukiwa T, Saijo Y: Targeted delivery of NK4 to multiple lung tumors by bone marrow-derived mesenchymal stem cells. Cancer Gene Ther 2007, 14:894-903.

15. Grisendi G, Bussolari R, Cafarelli L, Petak I, Rasini V, Veronesi E, De Santis G, Spano C, Tagliazzucchi M, Barti-Juhasz H, Scarabelli L, Bambi F, Frassoldati A, Rossi G, Casali C, Morandi U, Horwitz EM, Paolucci P, Conte P, Dominici M: Adipose-derived mesenchymal stem cells as stable source of tumor necrosis factor-related apoptosis-inducing ligand delivery for cancer therapy. Cancer Res 2010, 70:3718-3729.

16. Loebinger MR, Eddaoudi A, Davies D, Janes SM: Mesenchymal stem cell delivery of TRAIL can eliminate metastatic cancer. Cancer Res 2009, 69:4134-4142

17. Mohr A, Lyons M, Deedigan L, Harte T, Shaw G, Howard L, Barry F, O'Brien T, Zwacka R: Mesenchymal stem cells expressing TRAIL lead to tumour growth inhibition in an experimental lung cancer model. $J$ Cell Mol Med 2008, 12:2628-2643.

18. Kim SM, Lim JY, Park SI, Jeong CH, Oh JH, Jeong M, Oh W, Park SH, Sung YC, Jeun SS: Gene therapy using TRAIL-secreting human umbilical cord blood derived mesenchymal stem cells against intracranial glioma. Cancer Res 2008, 68:9614-9623.

19. Uchibori R, Okada T, Ito T, Urabe M, Mizukami H, Kume A, Ozawa K: Retroviral vector-producing mesenchymal stem cells for targeted suicide cancer gene therapy. J Gene Med 2009, 11:373-381.

20. Matuskova M, Hlubinova K, Pastorakova A, Hunakova L, Altanerova V, Altaner C, Kucerova L: HSV-tk expressing mesenchymal stem cells exert bystander effect on human glioblastoma cells. Cancer Lett 2010, 290:58-67.

21. Zischek C, Niess H, Ischenko I, Conrad C, Huss R, Jauch KW, Nelson PJ, Bruns C: Targeting tumor stroma using engineered mesenchymal stem cells reduces the growth of pancreatic carcinoma. Ann Surg 2009, 250:747-753.

22. Kucerova L, Altanerova V, Matuskova M, Tyciakova S, Altaner C: Adipose tissue-derived human mesenchymal stem cells mediated prodrug cancer gene therapy. Cancer Res 2007, 67:6304-6313.

23. Dembinski JL, Spaeth EL, Fueyo J, Gomez-Manzano C, Studeny M, Andreeff M, Marini FC: Reduction of nontarget infection and systemic toxicity by targeted delivery of conditionally replicating viruses transported in mesenchymal stem cells. Cancer Gene Ther 2010, 17:289-297.

24. Hakkarainen T, Sarkioja M, Lehenkari P, Miettinen S, Ylikomi T, Suuronen R, Desmond RA, Kanerva A, Hemminki A: Human mesenchymal stem cells lack tumor tropism but enhance the antitumor activity of oncolytic adenoviruses in orthotopic lung and breast tumors. Hum Gene Ther 2007, 18:627-641.

25. Komarova S, Kawakami Y, Stoff-Khalili MA, Curiel DT, Pereboeva L: Mesenchymal progenitor cells as cellular vehicles for delivery of oncolytic adenoviruses. Mol Cancer Ther 2006, 5:755-766.

26. Petrie Aronin CE, Tuan RS: Therapeutic potential of the immunomodulatory activities of adult mesenchymal stem cells. Birth Defects Res C Embryo Today 2010, 90:67-74

27. Djouad F, Plence P, Bony C, Tropel P, Apparailly F, Sany J, Noel D, Jorgensen C: Immunosuppressive effect of mesenchymal stem cells favors tumor growth in allogeneic animals. Blood 2003, 102:3837-3844.

28. Djouad F, Bony C, Apparailly F, Louis-Plence P, Jorgensen C, Noel D: Earlier onset of syngeneic tumors in the presence of mesenchymal stem cells. Transplantation 2006, 82:1060-1066.

29. Ohlsson LB, Varas L, Kjellman C, Edvardsen K, Lindvall M: Mesenchymal progenitor cell-mediated inhibition of tumor growth in vivo and in vitro in gelatin matrix. Exp Mol Pathol 2003, 75:248-255.

30. Le Blanc K, Tammik L, Sundberg B, Haynesworth SE, Ringden O: Mesenchymal stem cells inhibit and stimulate mixed lymphocyte cultures and mitogenic responses independently of the major histocompatibility complex. Scand J Immunol 2003, 57:11-20.

31. Dvorak HF: Tumors: wounds that do not heal. Similarities between tumor stroma generation and wound healing. N Engl J Med 1986, 315:1650-1659.

32. Feng $B$, Chen L: Review of mesenchymal stem cells and tumors: executioner or coconspirator? Cancer Biother Radiopharm 2009, 24:717-721.

33. Nakamizo A, Marini F, Amano T, Khan A, Studeny M, Gumin J, Chen J, Hentschel S, Vecil G, Dembinski J, Andreeff M, Lang FF: Human bone 
marrow-derived mesenchymal stem cells in the treatment of gliomas. Cancer Res 2005, 65:3307-3318.

34. Nakamura K, Ito Y, Kawano Y, Kurozumi K, Kobune M, Tsuda H, Bizen A, Honmou O, Nitsu Y, Hamada H: Antitumor effect of genetically engineered mesenchymal stem cells in a rat glioma model. Gene Ther 2004, 11:1155-1164.

35. Studeny M, Marini FC, Dembinski JL, Zompetta C, Cabreira-Hansen M, Bekele BN, Champlin RE, Andreeff M: Mesenchymal stem cells: potential precursors for tumor stroma and targeted-delivery vehicles for anticancer agents. J Natl Cancer Inst 2004, 96:1593-1603.

36. Wels J, Kaplan RN, Rafii S, Lyden D: Migratory neighbors and distant invaders: tumor-associated niche cells. Genes Dev 2008, 22:559-574.

37. Dwyer RM, Potter-Beirne SM, Harrington KA, Lowery AJ, Hennessy E, Murphy $J M$, Barry FP, O'Brien T, Kerin MJ: Monocyte chemotactic protein-1 (MCP-1) secreted by primary breast tumors stimulates migration of mesenchymal stem cells (MSCs). Clin Cancer Res 2007, 13:5020-5027.

38. Chamberlain G, Fox J, Ashton B, Middleton J: Concise review: mesenchymal stem cells: their phenotype, differentiation capacity, immunological features, and potential for homing. Stem Cells 2007, 25:2739-2749.

39. Ruster B, Gottig S, Ludwig RJ, Bistrian R, Muller S, Seifried E, Gille J, Henschler $R:$ Mesenchymal stem cells display coordinated rolling and adhesion behavior on endothelial cells. Blood 2006, 108:3938-3944.

40. Ringe J, Strassburg S, Neumann K, Endres M, Notter M, Burmester GR, Kaps C, Sittinger M: Towards in situ tissue repair: human mesenchymal stem cells express chemokine receptors CXCR1, CXCR2 and CCR2, and migrate upon stimulation with CXCL8 but not CCL2. J Cell Biochem 2007, 101:135-146.

41. Honczarenko M, Le Y, Swierkowski M, Ghiran I, Glodek AM, Silberstein LE: Human bone marrow stromal cells express a distinct set of biologically functional chemokine receptors. Stem Cells 2006, 24:1030-1041.

42. Von Luttichau I, Notohamiprodjo M, Wechselberger A, Peters C, Henger A, Seliger C, Djafarzadeh R, Huss R, Nelson PJ: Human adult CD34-progenitor cells functionally express the chemokine receptors CCR1, CCR4, CCR7, CXCR5, and CCR10 but not CXCR4. Stem Cells Dev 2005, 14:329-336.

43. Sordi V, Malosio ML, Marchesi F, Mercalli A, Melzi R, Giordano T, Belmonte N, Ferrari G, Leone BE, Bertuzzi F, Zerbini G, Allavena P, Bonifacio E, Piemonti L: Bone marrow mesenchymal stem cells express a restricted set of functionally active chemokine receptors capable of promoting migration to pancreatic islets. Blood 2005, 106:419-427.

44. Chamberlain G, Wright K, Rot A, Ashton B, Middleton J: Murine mesenchymal stem cells exhibit a restricted repertoire of functional chemokine receptors: comparison with human. PLoS One 2008, 3:e2934.

45. Shi M, Li J, Liao L, Chen B, Li B, Chen L, Jia H, Zhao RC: Regulation of CXCR4 expression in human mesenchymal stem cells by cytokine treatment: role in homing efficiency in NOD/SCID mice. Haematologica 2007, 92:897-904.

46. Wynn RF, Hart CA, Corradi-Perini C, O'Neill L, Evans CA, Wraith JE, Fairbairn L, Bellantuono I: A small proportion of mesenchymal stem cells strongly expresses functionally active CXCR4 receptor capable of promoting migration to bone marrow. Blood 2004, 104:2643-2645.

47. Potapova IA, Brink PR, Cohen IS, Doronin SV: Culturing of human mesenchymal stem cells as three-dimensional aggregates induces functional expression of CXCR4 that regulates adhesion to endothelial cells. J Biol Chem 2008, 283:13100-13107.

48. Zielske SP, Livant DL, Lawrence TS: Radiation increases invasion of genemodified mesenchymal stem cells into tumors. Int J Radiat Oncol Biol Phys 2009, 75:843-853

49. Klopp AH, Spaeth EL, Dembinski JL, Woodward WA, Munshi A, Meyn RE, Cox JD, Andreeff M, Marini FC: Tumor irradiation increases the recruitment of circulating mesenchymal stem cells into the tumor microenvironment. Cancer Res 2007, 67:11687-11695

50. Coussens LM, Werb Z: Inflammation and cancer. Nature 2002, 420:860-867.

51. Sarkar D, Vemula PK, Zhao W, Gupta A, Karnik R, Karp JM: Engineered mesenchymal stem cells with self-assembled vesicles for systemic cell targeting. Biomaterials 2010, 31:5266-5274.

52. Sato H, Kuwashima N, Sakaida T, Hatano M, Dusak JE, Fellows-Mayle WK, Papworth GD, Watkins SC, Gambotto A, Pollack IF, Okada H: Epidermal growth factor receptor-transfected bone marrow stromal cells exhibit enhanced migratory response and therapeutic potential against murine brain tumors. Cancer Gene Ther 2005, 12:757-768

53. Sasportas LS, Kasmieh R, Wakimoto $\mathrm{H}$, Hingtgen $\mathrm{S}$, van de Water JA, Mohapatra G, Figueiredo JL, Martuza RL, Weissleder R, Shah K: Assessment of therapeutic efficacy and fate of engineered human mesenchymal stem cells for cancer therapy. Proc Natl Acad Sci U S A 2009, 106:4822-4827.

54. Sonabend AM, Ulasov IV, Tyler MA, Rivera AA, Mathis JM, Lesniak MS: Mesenchymal stem cells effectively deliver an oncolytic adenovirus to intracranial glioma. Stem Cells 2008, 26:831-841.

55. Stoff-Khalili MA, Rivera AA, Mathis JM, Banerjee NS, Moon AS, Hess A, Roccon RP, Numnum TM, Everts M, Chow LT, Douglas JT, Siegal GP, Zhu ZB, Bender HG, Dall P, Stoff A, Pereboeva L, Curiel DT: Mesenchymal stem cells as a vehicle for targeted delivery of CRAds to lung metastases of breast carcinoma. Breast Cancer Res Treat 2007, 105:157-167.

56. Pereboeva L, Komarova S, Mikheeva G, Krasnykh V, Curiel DT: Approaches to utilize mesenchymal progenitor cells as cellular vehicles. Stem Cells 2003, 21:389-404.

57. Rubio D, Garcia-Castro J, Martin MC, de la Fuente R, Cigudosa JC, Lloyd AC, Bernad A: Spontaneous human adult stem cell transformation. Cancer Res 2005, 65:3035-3039.

58. Wang Y, Huso DL, Harrington J, Kellner J, Jeong DK, Turney J, McNiece IK: Outgrowth of a transformed cell population derived from normal human BM mesenchymal stem cell culture. Cytotherapy 2005, 7:509-519.

59. Bernardo ME, Zaffaroni N, Novara F, Cometa AM, Avanzini MA, Moretta A, Montagna D, Maccario R, Villa R, Daidone MG, Zuffardi O, Locatelli F: Human bone marrow derived mesenchymal stem cells do not undergo transformation after long-term in vitro culture and do not exhibit telomere maintenance mechanisms. Cancer Res 2007, 67:9142-9149.

60. Zhou YF, Bosch-Marce M, Okuyama H, Krishnamachary B, Kimura H, Zhang L, Huso DL, Semenza GL: Spontaneous transformation of cultured mouse bone marrow-derived stromal cells. Cancer Res 2006, 66:10849-10854.

61. Miura M, Miura Y, Padilla-Nash HM, Molinolo AA, Fu B, Patel V, Seo BM, Sonoyama W, Zheng JJ, Baker CC, Chen W, Ried T, Shi S: Accumulated chromosomal instability in murine bone marrow mesenchymal stem cells leads to malignant transformation. Stem Cells 2006, 24:1095-1103.

62. Tolar J, Nauta AJ, Osborn MJ, Panoskaltsis Mortari A, McElmurry RT, Bell S, Xia L, Zhou N, Riddle M, Schroeder TM, Westendorf JJ, Mclvor RS, Hogendoorn PC, Szuhai K, Oseth L, Hirsch B, Yant SR, Kay MA, Peister A, Prockop DJ, Fibbe WE, Blazar BR: Sarcoma derived from cultured mesenchymal stem cells. Stem Cells 2007, 25:371-379.

63. Li H, Fan X, Kovi RC, Jo Y, Moquin B, Konz R, Stoicov C, Kurt-Jones E, Grossman SR, Lyle S, Rogers AB, Montrose M, Houghton J: Spontaneous expression of embryonic factors and $\mathrm{p} 53$ point mutations in aged mesenchymal stem cells: a model of age-related tumorigenesis in mice. Cancer Res 2007, 67:10889-10898.

64. Karnoub AE, Dash AB, Vo AP, Sullivan A, Brooks MW, Bell GW, Richardson AL, Polyak K, Tubo R, Weinberg RA: Mesenchymal stem cells within tumour stroma promote breast cancer metastasis. Nature 2007, 449:557-563.

65. Muehlberg FL, Song YH, Krohn A, Pinilla SP, Droll LH, Leng X, Seidensticker M, Ricke J, Altman AM, Devarajan E, Liu W, Arlinghaus RB, Alt EU: Tissue-resident stem cells promote breast cancer growth and metastasis. Carcinogenesis 2009, 30:589-597.

66. Rhodes LV, Muir SE, Elliott S, Guillot LM, Antoon JW, Penfornis P, Tilghman SL, Salvo VA, Fonseca JP, Lacey MR, Beckman BS, McLachlan JA, Rowan BG, Pochampally R, Burow ME: Adult human mesenchymal stem cells enhance breast tumorigenesis and promote hormone independence. Breast Cancer Res Treat 2010, 121:293-300.

67. Galie M, Konstantinidou G, Peroni D, Scambi I, Marchini C, Lisi V, Krampera M, Magnani P, Merigo F, Montani M, Boschi F, Marzola P, Orru R, Farace P, Sbarbati A, Amici A: Mesenchymal stem cells share molecular signature with mesenchymal tumor cells and favor early tumor growth in syngeneic mice. Oncogene 2008, 27:2542-2551.

68. Spaeth EL, Dembinski JL, Sasser AK, Watson K, Klopp A, Hall B, Andreeff M, Marini F: Mesenchymal stem cell transition to tumor-associated fibroblasts contributes to fibrovascular network expansion and tumor progression. PloS one 2009, 4:e4992.

69. Bexell D, Gunnarsson S, Tormin A, Darabi A, Gisselsson D, Roybon L, Scheding $\mathrm{S}$, Bengzon J: Bone marrow multipotent mesenchymal stroma cells act as pericyte-like migratory vehicles in experimental gliomas. Mol Ther 2009, 17:183-190.

70. Yu JM, Jun ES, Bae YC, Jung JS: Mesenchymal stem cells derived from human adipose tissues favor tumor cell growth in vivo. Stem Cells Dev 2008, 17:463-473.

71. Shinagawa K, Kitadai Y, Tanaka M, Sumida T, Kodama M, Higashi Y, Tanaka S, Yasui W, Chayama K: Mesenchymal stem cells enhance growth and metastasis of colon cancer. Int J Cancer 2010. [Epub ahead of print] 
72. Zhu W, Xu W, Jiang R, Qian H, Chen M, Hu J, Cao W, Han C, Chen Y: Mesenchymal stem cells derived from bone marrow favor tumor cell growth in vivo. Exp Mol Pathol 2006, 80:267-274.

73. Wu Y, Wang J, Scott PG, Tredget EE: Bone marrow-derived stem cells in wound healing: a review. Wound Repair Regen 2007, 15(Suppl 1):S18-S26.

74. Wu Y, Chen L, Scott PG, Tredget EE: Mesenchymal stem cells enhance wound healing through differentiation and angiogenesis. Stem Cells 2007 25:2648-2659.

75. Mishra PJ, Mishra PJ, Humeniuk R, Medina DJ, Alexe G, Mesirov JP, Ganesan S, Glod JW, Banerjee D: Carcinoma-associated fibroblast-like differentiation of human mesenchymal stem cells. Cancer Res 2008, 68:4331-4339.

76. Bagley RG, Weber W, Rouleau C, Yao M, Honma N, Kataoka S, Ishida I, Roberts BL, Teicher BA: Human mesenchymal stem cells from bone marrow express tumor endothelial and stromal markers. Int J Oncol 2009, 34:619-627.

77. Qiao L, Xu Z, Zhao T, Zhao Z, Shi M, Zhao RC, Ye L, Zhang X: Suppression of tumorigenesis by human mesenchymal stem cells in a hepatoma model. Cell Res 2008, 18:500-507
78. Maestroni GJ, Hertens E, Galli P: Factor(s) from nonmacrophage bone marrow stromal cells inhibit Lewis lung carcinoma and B16 melanoma growth in mice. Cell Mol Life Sci 1999, 55:663-667.

79. Khakoo AY, Pati S, Anderson SA, Reid W, Elshal MF, Rovira, II, Nguyen AT, Malide D, Combs CA, Hall G, Zhang J, Raffeld M, Rogers TB, Stetler-Stevenson W, Frank JA, Reitz M, Finkel T: Human mesenchymal stem cells exert potent antitumorigenic effects in a model of Kaposi's sarcoma. J Exp Med 2006, 203:1235-1247.

\section{doi:10.1186/scrt25}

Cite this article as: Dwyer RM, et al:: Advances in mesenchymal stem cellmediated gene therapy for cancer. Stem Cell Research \& Therapy 2010, 1:25. 